\title{
Functional purification of the monocarboxylate transporter of the yeast Candida utilis
}

\author{
Fátima Baltazar · Fernanda Cássio · Cecília Leão
}

Received: 23 March 2006/ Accepted: 21 April 2006

(C) Springer Science+Business Media B.V. 2006

\begin{abstract}
Plasma membranes of the yeast, Candida utilis, were solubilized with octyl- $\beta$-D-glucopyranoside and a fraction enriched in the lactate carrier was obtained with DEAE-Sepharose anion-exchange chromatography, after elution with $0.4 \mathrm{M} \mathrm{NaCl}$. The uptake of lactic acid into proteoliposomes, containing the purified protein fraction and cytochrome $c$ oxidase, was dependent on a proton-motive force and the transport specificity was consistent with the one of $C$. utilis intact cells. Overall, we have obtained a plasma membrane fraction enriched in the lactate carrier of $C$. utilis in which the transport properties were preserved. Given the similarities between the lactate transport of $C$. utilis and the one of mammalian cells, this purified system could be further explored to screen for specific lactate inhibitors, with potential therapeutic applications.
\end{abstract}

Keywords Candida utilis $\cdot$ Functional reconstitution $\cdot$ Lactate carrier $\cdot$ Protein purification

\footnotetext{
F. Baltazar $(\bowtie) \cdot$ C. Leão

Life and Health Sciences Research Institute (ICVS),

School of Health Sciences, University of Minho, Braga, Portugal

e-mail: fbaltazar@ecsaude.uminho.pt

F. Cássio

Department of Biology, Biology Centre, University of

Minho, Braga, Portugal
}

\section{Introduction}

Proton-linked transport of monocarboxylates across the plasma membrane of mammalian cells is mediated by a group of membrane proteins known as MonoCarboxylate Transporters (MCTs). Based on sequence homologies, 14 members of the MCT family were identified. From these, six were functionally characterized and only MCT1-MCT4 catalyse proton-linked lactate transport (Halestrap and Meredith 2004). In yeasts, extensive work has been performed concerning the characterization of monocarboxylate transport (Casal and Leão 1995; Cássio and Leão 1993; Cássio et al. 1987, 1993; Gerós et al. 2000a; Leão and van Uden 1986) however, to date, no association has been reported with MCT related genes. In Sacharomyces cerevisiae a gene named JEN 1, which belongs to the sialateproton symporter family, was associated with the uptake of lactate and other monocarboxylates (Casal et al. 1999; Soares-Silva et al. 2003), while the MCT related genes identified in this yeast do not appear to be involved in the uptake of monocarboxylates (Makuc et al. 2001). However, functional characterization of the monocarboxylate transport of the yeast Candida utilis, revealed several similarities with the transport system of mammalian cells. Similarly to MCT1-MCT4 (Halestrap and Meredith 2004) monocarboxylate transport in $C$. utilis is a proton symport which 
accepts lactate and pyruvate (Leão and van Uden 1986; Cássio and Leão 1991, 1993; Cássio et al. 1993), and is inhibited by known mammalian MCT inhibitors, such as CHC ( $\alpha$-cyanohydroxycinnamic acid) and DIDS (4,4' di-isothiocyanostilbene-2,2'-disulfonic acid) (Gerós et al. 2000b). In addition, a polypeptide of approximately $40 \mathrm{kDa}$ was associated with $C$. utilis lactate transport (Gerós et al. 2000b), which is within the range of molecular weights identified for mammalian lactate transporters (Allen and Brooks 1994; Poole and Halestrap 1992, 1994).

In the present work, the plasma membrane proteins of the yeast $C$. utilis were solubilized, purified by DEAE-Sepharose chromatography and the activity of the lactate carrier was reconstituted into liposomes. This allowed a more positive identification of the protein involved in the lactate transport of $C$. utilis, which could also be an important contribution to the biochemical and genetic knowledge on lactate transport systems in yeasts.

\section{Materials and methods}

Preparation and solubilization of plasma membranes

Candida utilis PYCC 3092 was grown on medium containing $0.5 \%$ lactic acid, $\mathrm{pH} 4.8$ (Gerós et al. $2000 \mathrm{~b}$ ) and plasma membranes were prepared as described by Van Leeuwen et al. (1991). Membrane proteins were solubilized based on the procedure described by Allen and Brooks (1994). The solubilization mixture was prepared by addition of $1-2 \mathrm{mg}$ of membrane protein to the solubilization buffer with the following composition: $\quad 10-20 \mathrm{mg}$ octyl- $\beta$-D-glucopyranoside (octylglucoside), $10 \mathrm{mM}$ potassium phosphate, $50 \mathrm{mM} \mathrm{NaCl}, 10 \%$ (v/v) glycerol, $2 \mathrm{mM}$ benzamidine, $1 \mathrm{mM}$ DTT, $0.1 \mathrm{mM}$ PMSF, $\mathrm{pH} 7.4$, in a final volume of $1 \mathrm{ml}$.

L- $\left[\mathrm{U}-{ }^{14} \mathrm{C}\right]$ Lactic acid binding to plasma

membranes and SDS-PAGE analysis

Unless otherwise stated, aliquots of plasma membranes were incubated with $16.5 \mu \mathrm{M}$
L-[U- $\left.{ }^{14} \mathrm{C}\right]$ lactic acid $(3.7 \mathrm{~Bq}), \mathrm{pH} 7.4$, for $2 \mathrm{~h}$ at $30^{\circ} \mathrm{C}$, in the final volume of $40 \mu \mathrm{l}$, before SDSPAGE. At the end of the run, the lanes containing radioactive samples were used for counting of radioactivity (Gerós et al. 2000b). Non-radioactive membrane protein lanes were stained for protein with silver nitrate.

Fractionation of the solubilized plasma membranes

The DEAE-Sepharose column (1 ml) was washed with $10 \mathrm{mM}$ potassium phosphate $(\mathrm{pH} 7.4)$ and equilibrated in solubilization buffer (see above). The solubilized plasma membranes $(1 \mathrm{ml})$ were loaded onto the column and the bound material was eluted with a $\mathrm{NaCl}$ gradient of $0.2-1 \mathrm{M}$ (in solubilization buffer). The resulting protein fractions were collected and tested for their capacity to bind radioactive lactic acid (see above) and the protein electrophoretic pattern was analysed by SDS-PAGE with silver staining.

Preparation of proteoliposomes containing the purified lactate carrier protein and lactate transport assays

The incorporation of the solubilized membrane proteins into liposomes was performed by dilution of the detergent, following the procedure described by Matsushita et al. (1983). Prior to transport assays, the proteoliposomes were thawed at room temperature and bath-sonicated for 10-20 s until clear. At zero time, $18.6 \mu \mathrm{M}$ $\mathrm{L}-\left[\mathrm{U}-{ }^{14} \mathrm{C}\right]$ lactic acid was added to $200 \mu \mathrm{l}$ proteoliposomes pre-incubated at $26^{\circ} \mathrm{C}$ and energization was performed by addition of $15 \mathrm{mM}$ ascorbate, $150 \mu \mathrm{M}$ TMPD and $15 \mu \mathrm{M}$ cytochrome c. Aliquots of $7.5 \mu \mathrm{l}$ were withdrawn at suitable intervals and diluted with $2 \mathrm{ml}$ ice-cold $100 \mathrm{mM} \mathrm{LiCl}$. Samples were filtered on cellulose nitrate filters (pore size $0.45 \mu \mathrm{m}$, Schleider \& Schuell), washed with $2 \mathrm{ml} 100 \mathrm{mM} \mathrm{LiCl}$ and radioactivity was measured as indicated above.

Miscellaneous techniques

Protein was assayed according to the Lowry method using BSA as a standard. Isolation of 
cytochrome $c$ oxidase from bovine heart and determination of its activity was performed as described previously (Gerós et al. 1996). Phosphatidylethanolamine from $E$. coli was purified according to Viitanen et al. (1986). Protein samples were concentrated in Microsep $10 \mathrm{~K}$ centrifugal devices (Pall, Life Sciences), following the manufacturer's instructions.

\section{Results and discussion}

We showed previously that the lactate transporter of the plasma membrane of Candida utilis is able to bind $\mathrm{L}-\left[\mathrm{U}-{ }^{14} \mathrm{C}\right]$ lactic acid, which can be observed by a peak of radioactivity in SDS-PAGE (Gerós et al. 2000b) and this procedure was used to follow the transporter during purification. Thus, a first set of experiments was conducted to establish the optimal conditions of L-[U- $\left.-{ }^{14} \mathrm{C}\right]$ lactic acid binding to the yeast plasma membranes. As can be depicted from Fig. 1, protein labelling proved to be dependent on $\mathrm{pH}$, time of incubation, concentration of $\mathrm{L}-\left[\mathrm{U}_{-}{ }^{14} \mathrm{C}\right]$ lactic acid and concentration of protein in the isolated plasma membranes. Based on these results, we have selected $\mathrm{pH} 7.4,2 \mathrm{~h}$ incubation and $16.5 \mu \mathrm{M}$ $\mathrm{L}-\left[\mathrm{U}-{ }^{14} \mathrm{C}\right]$ lactic acid as incubation conditions for further experiments.

Solubilization of plasma membranes from C. utilis grown on lactic acid was conducted using a selection of non-denaturing detergents, namely octylglucoside, Triton X-100, and 3-[(3-cholamidopropyl)dimethylammonio]-1-propanesulfonate (CHAPS). These detergents were tested for their capacity to solubilize the yeast plasma membrane proteins as well as for the preservation of the carrier's capacity to bind L-[U- $\left.{ }^{14} \mathrm{C}\right]$ lactic acid (not shown). Octylglucoside was ultimately selected for further experiments because (i) it was able to solubilize the lactate carrier, preserving its capacity to bind radioactive lactate and (ii) its high CMC facilitated its removal from the protein mixtures, important for the preparation of proteoliposomes.

Solubilized plasma membrane protein fractionation was performed by ion exchange chromatography, using both a cation exchanger (SP-Sepharose) and an anion exchanger (DEAE-
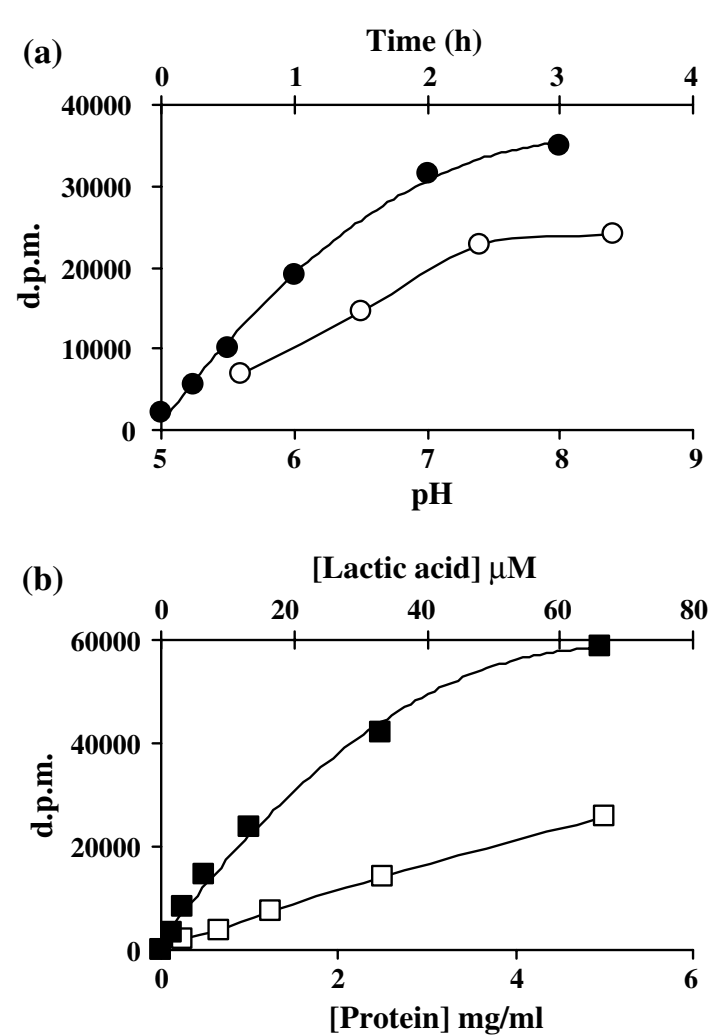

Fig. 1 Factors influencing the magnitude of the peak of radioactivity resulting from binding of $\mathrm{L}-\left[\mathrm{U}-{ }^{14} \mathrm{C}\right]$ lactic acid to the lactate carrier protein of $C$. utilis detected in SDSPAGE. (a) effect of $\mathrm{pH}(\bigcirc)$ and time of incubation with radioactive lactic acid (O); (b) effect of concentration of radioactive lactic acid ( $\boldsymbol{\square})$ and concentration of membrane protein $(\square)$ on the magnitude of the radioactive peak. Data points represent the radioactivity associated with the lactate carrier. The standard mixture contained plasma membranes $(5 \mathrm{mg} / \mathrm{ml})$ and $16.5 \mu \mathrm{M}$ L- $\left[\mathrm{U}_{-}{ }^{14} \mathrm{C}\right]$ lactic acid $(3.7 \mathrm{kBq})$ in $10 \mathrm{mM}$ Tris, $1 \mathrm{mM}$ EDTA, at $\mathrm{pH} 7.4$ and was incubated for $2 \mathrm{~h}$ at $30^{\circ} \mathrm{C}$, in the final volume of $40 \mu \mathrm{l}$. KPi was replaced by Mes and Bis-Tris when incubations were performed at $\mathrm{pH} 5.6$ and $\mathrm{pH} 6.5$, respectively

Sepharose), with a gradient of $0.2-1 \mathrm{M} \mathrm{NaCl}$. Protein fractions were incubated with radioactive lactic acid and analysed by SDS-PAGE. Purification with SP-Sepharose was not possible since, under the conditions used, the lactate carrier did not bind to the column. On the other hand, most of the membrane protein (about $85 \%$ ) bound to DEAE-Sepharose (not shown) and lactate carrier was eluted with the $\mathrm{NaCl}$ gradient. This fact suggests that most of the plasma membrane protein of C. utilis is negatively charged at $\mathrm{pH}$ 7.4. The results of protein fractionation by DEAE- 
Sepharose are presented in Fig. 2. Despite the fact that most of the solubilized plasma membrane protein (about 60\%), was eluted up to $0.2 \mathrm{M} \mathrm{NaCl}$ (not shown), binding of radioactive lactic acid was only detected in the $0.4 \mathrm{M} \mathrm{NaCl}$ fraction (Fig. 2, lane 5). Thus, this anion exchanger allowed the purification of the lactate transport system of $C$. utilis, which is in agreement with the literature reporting the purification of the lactate transporters of rat and rabbit erythrocytes using anion-exchange chromatography (Poole and Halestrap 1992, 1994). As shown in Fig. 2, the peak of radioactivity appears to be associated with a protein molecular weight around $30 \mathrm{kDa}$. This molecular weight is also within the range reported for the plasma membrane lactate carriers of rat hepatocytes (Welch et al. 1984), rat and rabbit erythrocytes (Poole and Halestrap 1992; Jennings and Adams-Lackey 1982) and rat skeletal muscle (McCullagh and
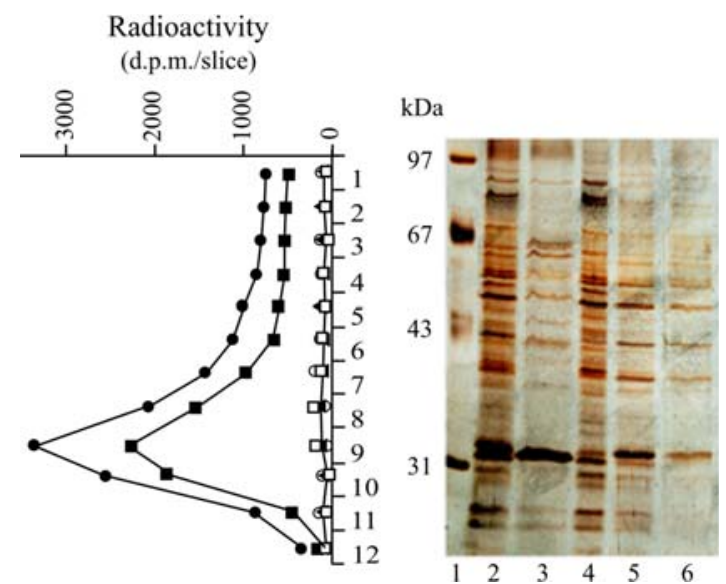

Fig. 2 Analysis of the membrane protein fractions after separation by DEAE-Sepharose chromatography. The chart on the left shows a representative result from an experiment of $\mathrm{L}-\left[\mathrm{U}_{-}{ }^{14} \mathrm{C}\right]$ lactic acid binding to the protein fractions: solubilized plasma membranes $(\mathbf{O})$, column flow through (O), $0.2 \mathrm{M} \mathrm{NaCl}$ eluate $(\mathbf{\Delta}), 0.4 \mathrm{M} \mathrm{NaCl}$ eluate (घ), $0.6 \mathrm{M} \mathrm{NaCl}$ eluate ( $\square$ ). Protein was incubated with radioactive L-lactic acid followed by SDS-PAGE and gel slicing. Data points represent the radioactivity present in each gel slice. The gel on the right shows the electrophoretic pattern of the protein eluted fractions: lane 1, molecular-mass markers; lane 2, solubilized plasma membranes; lane 3, DEAE-Sepharose flow through; lanes 4, 5 and 6 correspond to $0.2,0.4$ and $0.6 \mathrm{M} \mathrm{NaCl}$ column eluates, respectively. Protein contents in lanes 2-6 were 5, $3.5,5,5$ and $2.5 \mu \mathrm{g}$, respectively. The gel was stained with silver nitrate
Bonen 1995). As can be seen in Fig. 2 (lane 5), there are still other polypeptides of different molecular weights, present in the lactate carrier enriched fraction, however, at this point we cannot discard their involvement in C. utilis lactate transport. For example, catalytic activity and plasma membrane translocation of MCT1 and MCT4 requires a chaperone protein named CD147, which exhibits several protein bands of $35-65 \mathrm{kDa}$ in SDS-PAGE, characteristic of its glycosylation states (Kirk et al. 2000).

In order to investigate if the lactate transporter was still functional after purification, the $0.4 \mathrm{M}$ fraction was incorporated in an artificial E. coli phospholipid bilayer, containing cytochrome $c$ oxidase, as the proton-motive-force generating system. The resulting proteoliposomes were used to follow the uptake of $\mathrm{L}-\left[\mathrm{U}_{-}{ }^{14} \mathrm{C}\right]$ lactic acid along time. Under these conditions, about $100 \%$ of the protein was incorporated (data not shown). The addition of suitable electron donors to the system caused an increase of about 4-fold in the uptake of radioactive lactic acid (Fig. 3). The uptake of radioactive lactic acid in control proteoliposomes without membrane protein, under the same conditions, was negligible (data not shown). The

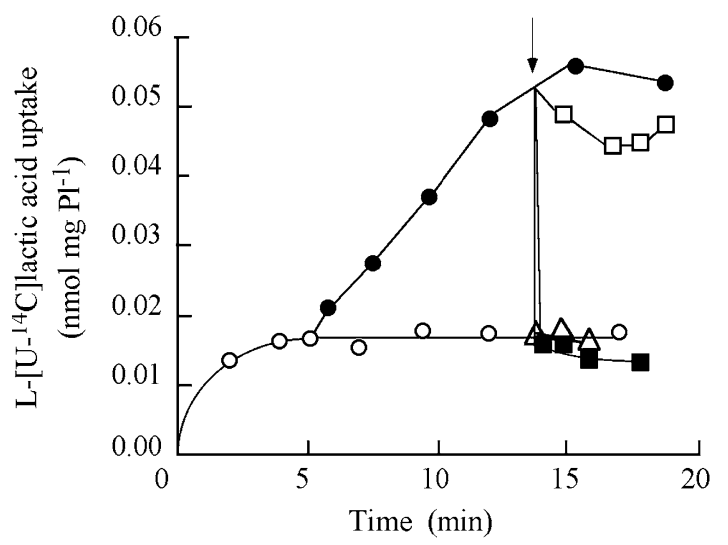

Fig. 3 Time-course uptake of $\mathrm{L}_{-}\left[\mathrm{U}-{ }^{14} \mathrm{C}\right]$ lactic acid in proteoliposomes containing the purified lactate carrier. Uptake of radioactive lactic acid $(18.6 \mu \mathrm{M})$ was performed at $\mathrm{pH} 6.2$ and $26^{\circ} \mathrm{C}$, either with $(0)$ or without $(\mathrm{O})$ energization. For energization of the system, at $t=5 \mathrm{~min}$, $15 \mathrm{mM}$ ascorbate, $0.015 \mathrm{mM}$ cytochrome $\mathrm{c}$ and $0.15 \mathrm{mM}$ TMPD, were added to the reaction mixture (proteoliposomes with radioactive acid). At the time indicated by the arrow, $10 \mu \mathrm{M}$ FCCP $(\Delta), 20 \mathrm{mM}$ pyruvic acid (匹) and $20 \mathrm{mM}$ citric acid $(\square)$ were added 
addition of the protonophore FCCP at maximal accumulation caused a rapid efflux of the accumulated radioactive lactate (Fig. 3), suggesting the involvement of proton-motive force in lactate transport. The specificity of the lactate transport system was investigated by the addition of either pyruvic or citric acids to the proteoliposomes, after accumulation of radioactive lactate. The results showed that only pyruvate was able to promote the efflux of radioactive lactate (Fig. 3), consistent with the fact that the transporter in either C. utilis intact cells (Leão and van Uden 1986) or hybrid vesicles (Gerós et al. 1996), accepts lactate and other monocarboxylates but not di- or tricarboxylates.

In summary, the present study represents a successful solubilization and purification of the lactate carrier from the plasma membranes of the yeast $C$. utilis, in a functionally active form. Our procedure can contribute to the identification of the protein component(s) involved in lactate transport in other yeast species. In addition, since MCTs have a role in pathologies with high glycolytic activity (e.g. solid tumors), by promoting the efflux of the accumulating organic acids (e.g. lactic acid), specific inhibition of these transporters would result in intracellular acidification, leading to tumor cell apoptosis. Taking into consideration the similarities between the lactate transport system of $C$. utilis and the one of mammalian cells, we believe that our yeast system might be further explored to study monocarboxylate transport inhibition, and to screen for MCT specific inhibitors with potential therapeutic applications.

Acknowledgement F. B. received a post-doctoral fellowship from Fundação para a Ciência e a Tecnologia (SFRH/BPD/7170/2001).

\section{References}

Allen PJ, Brooks GA (1994) Partial purification and reconstitution of the sarcolemmal L-lactate carrier from rat skeletal muscle. Biochem J 303:207-212

Casal M, Leão C (1995) Utilization of short-chain monocarboxylic acids by the yeast Torulaspora delbrueckii: specificity of the transport systems and their regulation. Biochim Biophys Acta 1267:122-130
Casal M, Paiva S, Andrade RP, Gancedo C, Leão C (1999) The lactate-proton symport of Saccharomyces cerevisiae is encoded by JEN1. J Bacteriol 181:2620-2623

Cássio F, Leão C (1991) Low- and high-affinity transport systems for citric acid in the yeast Candida utilis. Appl Environ Microbiol 57:3623-3628

Cássio F, Leão C (1993) A comparative study on the transport of L(-)malic acid and other short-chain carboxylic acids in the yeast Candida utilis: evidence for a general organic acid permease. Yeast 9:743-752

Cássio F, Corte-Real M, Leão C (1993) Quantitative analysis of proton movements associated with the uptake of weak carboxylic acids. The yeast Candida utilis as a model. Biochim Biophys Acta 1153:59-66

Cássio F, Leão C, van Uden N (1987) Transport of lactate and other short-chain monocarboxylates in the yeast Saccharomyces cerevisiae. Appl Environ Microbiol 53:509-513

Gerós H, Cássio F, Leão C (1996) Reconstitution of lactate proton symport activity in plasma membrane vesicles from the yeast Candida utilis. Yeast 12:12631272

Gerós H, Cássio F, Leão C (2000a) Utilization and transport of acetic acid in Dekkera anomala and their implications on the survival of the yeast in acidic environments. J Food Prot 63:96-101

Gerós H, Baltazar F, Cássio F, Leão C (2000b) L$\left[\mathrm{U}-{ }^{14} \mathrm{C}\right]$ Lactate binding to a $43 \mathrm{kDa}$ protein in plasma membranes of Candida utilis. Microbiology 146:695699

Halestrap AP, Meredith D (2004) The SLC16 gene familyfrom monocarboxylate transporters (MCTs) to aromatic amino acid transporters and beyond. Pflugers Arch 447:619-628

Jennings ML, Adams-Lackey M (1982) A rabbit erythrocyte membrane protein associated with L-lactate transport. J Biol Chem 257:12866-12871

Kirk P, Wilson MC, Heddle C, Brown MH, Barclay AN, Halestrap AP (2000) CD147 is tightly associated with lactate transporters MCT1 and MCT4 and facilitates their cell surface expression. EMBO J 19:3896-3904

Leão C, van Uden N (1986) Transport of lactate and other short-chain monocarboxylates in the yeast Candida utilis. Appl Microbiol Biotechnol 23:389-393

Makuc J, Paiva S, Schauen M, Krämer R, André B, Casal M, Leão C, Boles E (2001) The putative monocarboxylate permeases of the yeast Saccharomyces cerevisiae do not transport monocarboxylic acids across the plasma membrane. Yeast 18:1131-1143

Matsushita K, Patel L, Gennis RB, Kaback HR (1983) Reconstitution of active transport in proteoliposomes containing cytochrome $c$ oxidase and lac carrier protein purified from Escherichia coli. Proc Natl Acad Sci 80:4889-4893

McCullagh KJA, Bonen A (1995) L(+)-Lactate binding to a protein in rat skeletal muscle plasma membranes. Can J Appl Physiol 20:112-124

Poole RC, Halestrap AP (1992) Identification and partial purification of the erythrocyte L-lactate transporter. Biochem J 283:855-862 
Poole RC, Halestrap AP (1994) N-terminal sequence analysis of the rabbit erythrocyte lactate transporter suggests identity with the cloned monocarboxylate transporter protein MCT1. Biochem J 303:755-759

Soares-Silva I, Schuller D, Andrade RP, Baltazar F, Cássio F, Casal M (2003) Functional expression of the lactate permease Jen1p of Saccharomyces cerevisiae in Pichia pastoris. Biochem J 376:781-787

Van Leeuwen CCM, Postma E, Van der Broek PJA, Steveninck J (1991) Proton-motive force-driven D-galactose transport in plasma membrane vesicles from the yeast Kluyveromyces marxianus. J Biol Chem 266:12146-12151

Viitanen P, Newman NJ, Foster DL, Wilson TH, Kaback HR (1986) Purification, reconstitution and characterization of the lac permease of Escherichia coli. Method Enzymol 125:429-452

Welch SG, Metcalfe HK, Monson JP, Cohen RD, Henderson RM, Iles RA (1984) L(+)-Lactate binding to preparations of rat hepatocyte plasma membranes. J Biol Chem 259:15264-15271 